\title{
LANGUAGE AND IDENTITY: A REAPPRAISAL OF NEGERI SEMBILAN MALAY LANGUAGE
}

\section{Idris Aman, Mohammad Fadzeli Jaafar" and Norsimah Mat Awal}

School of Language Studies and Linguistics, Faculty of Social Sciences and Humanities, Universiti Kebangsaan Malaysia, Selangor, Malaysia

"Corresponding author: fadzeli@ukm.edu.my

Published online: 24 April 2019

To cite this article: Idris Aman, Mohammad Fadzeli Jaafar and Norsimah Mat Awal. 2019. Language and identity: A reappraisal of Negeri Sembilan Malay language. Kajian Malaysia 37(1): 27-49. https://doi.org/10.21315/km2019.37.1.2

To link to this article: https://doi.org/10.21315/km2019.37.1.2

\begin{abstract}
Negeri Sembilan, as one of the states in Malaysia, has been greatly influenced by the Minangkabau culture, in particular the Perpatih custom which led to the socalled misunderstanding that Negeri Sembilan Malay language (NSML) resembles or is similar to the Minangkabau language. This article aims to describe the distinctive phonological features of Negeri Sembilan language to mark its identity and therefore prove that it is free from the Minangkabau linguistic influence. This study utilises the Swadesh word list of 100 words to test pronunciation. Thirty informants were involved and they are speakers of the Negeri Sembilan Malay language and speakers of the Minangkabau language both in Malaysia and Sumatera. The research was conducted in Kuala Pilah, Rembau, and Beranang in Malaysia, while in Indonesia the data was collected in Paya Kumbuh, Bukit Tinggi, and Padang. Based on the 100 words tested, this study observed 17 pronunciation patterns in Negeri Sembilan language that are distinct from the Minangkabau language, specifically they are 10 vowel sounds patterns and 7 consonant sounds patterns. From these 17 patterns, 13 only occur in NSML and the remaining 4 patterns occur in both NSML and the Minangkabau language. Hence, it can be concluded that the Negeri Sembilan language has its own distinctive phonological identity, thus distinguishing it from the Minangkabau linguistic features.
\end{abstract}

Keywords: Negeri Sembilan Malay language, Minangkabau language, phonological features, identity 


\section{INTRODUCTION}

Identity is referred to as the capacity for self-reflection and self-awareness (Leary and Tangney 2003). Developing an identity is an important social process because each individual or social group would like to be known by its own identity which distinguishes it from other individuals or other social groups. The assertion that language develops an identity and identity is represented by language is not new, in fact, it has been discussed at length by both linguists and sociologists, i.e, Tabouret-Keller (1997), Kramsch (1998), Crystal (2003), and Fairclough (2003). In general, they stressed that language and identity are inter-related, in fact, language is said to be one of the best markers to determine the identity of an individual or a society. According to Le Page and Tabouret-Keller (1985), language act is also an act of identity. This implies that language and identity is an inseparable pair. Following Wardhaugh and Fuller (2015), identity is constructed through a variety of linguistic means. The language and identity relationship is very strong to the extent that one linguistic feature is capable of showing a person's membership in a group. For example, a phonemic feature is sufficient to include or remove a person in a social group (Tabouret-Keller 1997). As such, an individual's identity and social identity is represented by the language features used, from phonetic features or pronunciation, lexical, syntax structures, as well as a personal name. In fact, language itself can serve as a symbol that would motivate someone to die or be killed for it (Tabouret-Keller 1997).

In the Malaysian Peninsula, the variety of Malay language spoken in Negeri Sembilan is rather unique compared to other Malay varieties spoken in the neighbouring states, for example the final half-low back vowel $\curvearrowright$ (boto). According to Asmah (1985), the native inhabitant's language of this area belongs to the Southern Malay dialect of the Malay Peninsula which covers lower Perak to Johor. Historically, this province received influence from their neighbouring culture, such as Melaka and Johor, and Minangkabau, Sumatra. However, culturally, the dominant cultural influence is the Minangkabau culture brought by the Minangkabau migrants from Western Sumatra (now part of Indonesia). Hendon (1966, xi) named the Minangkabau migrants as "colonists from Sumatra". It is quite difficult to reliably determine the date of their arrival in the Malay Peninsula, probably before the establishment of the Sultanate of Melaka (Rahilah and Nelmawarni 2008). However, according to de Jong (1952) and Winstedt (1934), the massive migration of Minangkabau people to Malay Peninsula started in the 15th century or earlier. Hendon (1966) stated that at the beginning of the 17th century, Minangkabau people had lived in the remote areas of Melaka namely, Naning and Rembau (now part of Negeri Sembilan), while Asmah (1985) mentioned it in the 18th century. 
Minangkabau migrants were well received by the locals and their interactions are very close in terms of culture and language (Ajid 2002). As such, culture and language contact took place, further leading to the process of assimilation. The most prominent was the Minangkabau Perpatih custom which was later adopted as the social system in the area. To date, a large number of Negeri Sembilan residents who are categorised as "Malay" are still practicing the Perpatih custom and social system such as values, family, politics, economy, custom and stratification (Nordin 1982).

The implication of the situation is that misunderstanding often exists regarding Negeri Sembilan. When Negeri Sembilan is mentioned, the public would most often refer to it as "Minangkabau". This stereotype is most significant in the case of language. Some people perceived that the Malay language variety spoken in Negeri Sembilan is a variety of the Minangkabau language. Mohd Pilus (1978), for example, mentioned that the current Negeri Sembilan Malay language (NSML) is influenced by Minangkabau language (MgL). Asmah (1985) wrote that NSML is a dialect brought from Minangkabau. Reniwati (1990) concluded that there is a similarity in the phoneme system between NSML and MgL, and finally Reniwati, Midawati and Noviatri (2017) categorised NSML as a variation of MgL. This stereotype is also widespread among the general public outside of Negeri Sembilan leading to the belief that NSML experienced a MgL hegemony. At present, there are Minangkabau people residing in various parts of the Malay Peninsula (Rahilah and Nelmawarni 2008). Some of them still speak the Minangkabau language in their communities, such as in Gombak, Kuang, Ulu Langat, Semenyih and Beranang, Selangor. However, in Negeri Sembilan, the area where a majority of its population are Minangkabau and still using MgL is only in Lenggeng (Jamaludin 1999), which is adjacent to Beranang, Selangor.

Is the steoretypical belief that because of the strong and dominant Minangkabau culture that the MgL has somehow exerted its influence on NSML true? After more than six centuries, (Rahilah and Nelmawarni 2008) would not Negeri Sembilan have its own linguistic identity? In our opinion, these issues should be scientifically and empirically examined. Hence, this study aims to identify and describe the distinctive features of NSML phonological features compared to MgL.

\section{NEGERI SEMBILAN MALAY LANGUAGE}

The earliest known study on NSML was conducted by Hendon (1966) in Kuala Pilah. The scope of the previous studies on NSML can be grouped into two, namely, the "linguistic dimensions" and "extra-linguistic dimension". However, majority of the studies on NSML were more focused on the linguistic dimensions. 
By linguistic dimension, it means discussions were purely on the linguistic aspects. The description of such dimension can be sub-categorised into two: the specific description and the comparative description. Specific description means describing NSML solely without comparing it with other languages. Such a description of NSML has been conducted by several studies. The specific language description can be divided into several aspects, namely, general aspect as by Yeop Johari (1989; 1994), Mohd Faiz (1998), and Jamaludin (1999). The phonological aspect was taken up by Hendon (1966), Sharman (1973; 1974), Mohd Pilus (1978), Yeop Johari (1984), Asmah (1985), Ibrahim and Ibrahim (1990), Arbak (1994), and Ajid (2002). The morphological aspects were described by Hendon (1966), lexical by Yeop Johari (1986) and Ajid (2002), and syntax by Ramli (2002). The semantic aspect has been examined by Norsimah and Nur Liyana (2011) and Norsimah, Mohammad Fadzeli and Nur Liyana (2014). It is clear that the phonological aspects were given the most attention by the researchers. The earliest known NSML phonological description is by Hendon (1966), and later by Sharman (1973; 1974), Mohd Pilus (1978), Yeop Johari (1984), Asmah (1985), Ibrahim and Ibrahim (1990), Arbak (1994), and Ajid (2002).

Second, comparative descriptions are descriptions of NSML linguistic aspects and comparing them to other languages. Two languages that are often compared with NSML are MgL and the standard variety of the Malay language. Mohd Pilus (1978) compared NSML with standard Malay. There are also several studies that compared NSML with MgL (Reniwati 1990; 2012; Media Sandra 2002; Reniwati and Ab. Razak 2015). Surprisingly, Reniwati, Midawati and Noviatri (2017) categorizes NSML under MgL. Reniwati (1990) compares the phonemic aspect. However, Reniwati (2012), Media Sandra (2002), and Reniwati and Ab. Razak (2015) look at lexical comparisons.

By contrast, work of the extra-linguistic dimensions did not only describe the NSML linguistic dimensions but also relates the linguistic input with other aspects. Idris et al. (2014) examines the question of understanding archaic lexical items and social change, Yeop Johari (1989) examines the relationship of language with culture, Norsimah, Idris and Mohammad Fadzeli (2013) and Idris, Mohammad Fadzeli and Norsimah (2015) examine attitude and identity values.

Although there are a number of previous works on NSML covering various dimensions and aspects, the problems highlighted above have not been discussed. Even though there have been a number of phonological descriptions done, the descriptions were just from linguistic dimensions. Phonological description from the extra-linguistic dimension has not been found and only Reniwati (1990) has conducted a comparative phonological study with MgL. In addition, the comparative description done was not "extra" in nature because it only focused on the linguistics aspect. Although the question of identity and attitudes became the 
focus of Norsimah, Idris and Mohammad Fadzeli (2013), and Idris, Mohammad Fadzeli and Norsimah (2015), the descriptions were based on the understanding of a set of archaic lexical items and did not describe the phonological aspect. Hence, this study looks at the extra-linguistic dimension and in this case the extralinguistic dimension refers to the distinctive features that marked the identitiy of NSML speakers.

\section{RESEARCH METHOD AND PROCEDURES}

The aims of this study are to identify and describe the distinctive features of NSML phonological features compared to $\mathrm{MgL}$ and the method employed is a pronunciation test. Phonology is said to be a more reasonable linguistic element to show language variation (Labov 1972; Trudgill 1974; Asmah 1985) and it is also more practical (Milroy 1987). Comparison with MgL would also be undertaken because the identity of an entity is more significant when it is compared with another entity.

Therefore, three categories of informants were involved, namely NSML speaker, MgL speakers in Malaysia, and MgL speakers at its original place - West Sumatera. The informants' criterion are: permanent residents, men and women in the area and aged 40 and above. Thirty informants were chosen based on the criteria mentioned above. The breakdown of the informants is as follows: 15 informants are NSML speakers and 15 are MgL speakers (7 Malaysian Minangkabau; 8 Sumatran Minangkabau). Based on the objective of this research, it does not require many informants because this study gives priority to actual language use. Chambers and Trudgill (1980) mentioned that taking into account the survey area and the objectives of the study, the appropriate minimum number of informants is 25 .

NSML informants were from the surrounding villages around Seri Menanti, Tanjung Ipoh, and Batu Kikir in Kuala Pilah, and around Batu Hampar and Tanah Datar in Rembau. The MgL informants in Malaysia were those who lived in Beranang, Selangor and the adjacent villages in Negeri Sembilan, namely Kampung Dacing in Lenggeng. The Sumatran MgL informants were those who lived in Bukit Tinggi and Padang, Indonesia.

The language data was obtained from the articulation of words listed on a word list that was developed based on the latest Swadesh word list (Wikipedia n.d.). The Swadesh list contains 100 words translated to standard Malay language but with innovation by replacing some words that have unique NSML sounds based on Idris, Mohammad Fadzeli and Norsimah (2015). Informants were requested to pronounce the words listed one by one in their respective languages - NSML or Minangkabau individually. 
The process of gathering and interviewing the informants were conducted by the researchers and assisted by the Universiti Kebangsaan Malaysia linguistic graduate research assistants. The research process began with an informal introduction. Then, the researcher requested the informant to pronounce the words in their own language accent. The actual language used was recorded. A session with each informant took about 20-30 minutes. Data analysis starts by listening to the informants' pronunciation from the recording. The coding pronunciation form was prepared to facilitate the coding of actual pronunciation of each informant. This was then followed by counting the number of occurances, for example, the final half-low back vowel [0] at the end of the word [namo]. There were 15 respondents involved and the total number of words with the final halflow back vowel [0] is 8 . Therefore the total number of occurences is $15 \times 8=120$. The actual number of pronunciation of the vowel [0] is 119 times. Hence, 119 is divided by 120 and multiplied by $100 \%$ which equals to $99 \%$. This method of calculation is applied to all distinctive vowels and consonants sounds as shown in Tables 1 and 2.

Overall, two types of pronunciation were identified, namely the norm and non-norm sound which was marked as "/" and " 0 " respectively. The norm sound was based on previous descriptions of the NSML such as Hendon (1966), Sharman (1974), Yeop Johari (1984), and Asmah (1985). In addition, the non-norm sound was also transcribed in the form. Then, the actual norm sound realisation was calculated based on frequencies and percentage. Meanwhile, specifically for $\mathrm{MgL}$ informants, researchers were assisted by the Universiti Kebangsaan Malaysia linguistic doctoral student from Padang, Sumatra, who is a native speaker of the language. She was appointed as the $\mathrm{MgL}$ consultant for this research. For each data analysis involving pronunciation of $\mathrm{MgL}$, consultation and verification with the $\mathrm{MgL}$ consultant was carried out. For that reason, only norm sound was considered. Due to the focus of the study is on NSML phonological aspect, the frequency of $\mathrm{MgL}$ sound was not calculated. Finally, the findings of this study are discussed based on the objectives highlighted.

\section{RESULTS}

This study has identified 17 phonological patterns which are 10 vowel sound patterns and 7 consonant sound patterns. These are the distinctive features of NSML. These 17 features were identified through the pronunciation test. Out of these 17 features, 13 were found to be distinctive features of NSML and the remaining are found both in NSML and MgL. This means that there are 13 features that are unique to NSML, with 9 of them being vowel sounds and 4 being consonants. Overall, through the test conducted, the pronunciation 
percentage of the distinctive feature is considered high; with the lowest being $89 \%$ on only one phonological feature, i.e. initial half-low back vowel [0] of an open syllable. The other 16 phonological features scored more than $90 \%$ and 9 of the features scored a $100 \%$ on the pronunciation test. The pronunciation percentage value of a particular sound feature marks and verifies its variation. Some of the pronunciation did not get the score of $100 \%$ because there were informants who were speaking in standard Malay language. The distinctive features are displayed in Table 1.

Table 1: Distinctive features of NSML vowel features with MgL according to position in words

\begin{tabular}{|c|c|c|c|c|c|}
\hline \multicolumn{6}{|c|}{ Vowel } \\
\hline & A & & & B & $\mathrm{C}$ \\
\hline & $\begin{array}{l}\text { Negeri Sembilan Malay } \\
\text { Language (NSML) }\end{array}$ & $\begin{array}{l}\text { No. of } \\
\text { words }\end{array}$ & $\begin{array}{l}\text { Say } \\
\text { rate }\end{array}$ & $\begin{array}{l}\text { Minangkabau Language } \\
(\mathrm{MgL})\end{array}$ & Status \\
\hline $\mathrm{a}$ & $\begin{array}{l}\text { Final half-low back vowel [0]. } \\
\text { Eg: [namo] }\end{array}$ & 8 & $\begin{array}{l}119 \\
(99)\end{array}$ & $\begin{array}{l}\text { Final half-high back vowel [o]. } \\
\text { Eg: [namo] }\end{array}$ & $\begin{array}{l}\text { Non- } \\
\text { identical }\end{array}$ \\
\hline $\mathrm{b}$ & $\begin{array}{l}\text { Initial half-low back vowel [०]. } \\
\text { Eg: [oyay] }\end{array}$ & 1 & $\begin{array}{c}14 \\
(93)\end{array}$ & $\begin{array}{l}\text { Initial high back vowel [u]. } \\
\text { Eg: [uray] }\end{array}$ & $\begin{array}{l}\text { Non- } \\
\text { identical }\end{array}$ \\
\hline $\mathrm{c}$ & $\begin{array}{l}\text { Initial open syallable of half- } \\
\text { low back vowel [0]. Eg: [koyen] }\end{array}$ & 27 & $\begin{array}{l}361 \\
(89)\end{array}$ & $\begin{array}{l}\text { Initial open syllables of low } \\
\left.\text { front vowel [a]. Eg: [kari }{ }^{y} a y\right]\end{array}$ & $\begin{array}{l}\text { Non- } \\
\text { identical }\end{array}$ \\
\hline d & $\begin{array}{l}\text { Half-low front vowel }[\varepsilon] \text { at } \\
\text { close ended words. Eg: [omp } 2 \text { ?] }\end{array}$ & 9 & $\begin{array}{l}131 \\
(97)\end{array}$ & 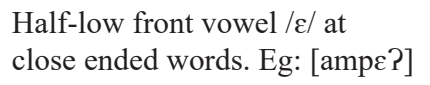 & Identical \\
\hline $\mathrm{e}$ & $\begin{array}{l}\text { Half-high back vowel [o] at } \\
\text { words ending with non-voice } \\
\text { dental alveolar [t]. Eg: [mulot] }\end{array}$ & 5 & $\begin{array}{c}75 \\
(100)\end{array}$ & $\begin{array}{l}\text { Diphthongs [ui] and ended } \\
\text { with glottal [?]. Eg: [mului?] }\end{array}$ & $\begin{array}{l}\text { Non- } \\
\text { identical }\end{array}$ \\
\hline $\mathrm{f}$ & $\begin{array}{l}\text { Half-high back vowel }[\mathrm{o}] \text { at } \\
\text { words ending with a voiced } \\
\text { Palatal Nasals consonant }[\mathrm{y}] \text {. } \\
\text { Eg: [kampon] }\end{array}$ & 6 & $\begin{array}{c}89 \\
(99)\end{array}$ & $\begin{array}{l}\text { High back vowel }[\mathrm{u}] \text { at the end } \\
\text { of words with semi vowel } \\
\left.\text { insertion }{ }^{\mathrm{w}}\right] \text { followed by low } \\
\text { front vowel [a]. Eg: [kampuwan] }\end{array}$ & $\begin{array}{l}\text { Non- } \\
\text { identical }\end{array}$ \\
\hline $\mathrm{g}$ & $\begin{array}{l}\text { Half-high front vowel [e] at } \\
\text { the end of open ended words. } \\
\text { Eg: [bibe]. }\end{array}$ & 4 & $\begin{array}{c}60 \\
(100)\end{array}$ & $\begin{array}{l}\text { High front vowel [i] followed } \\
\text { by semi- vowel insertion }\left[{ }^{\mathrm{y}}\right] \text { and } \\
\text { low front vowel }[\mathrm{a}] . \text { Eg: }\left[\text { bibi }^{\mathrm{y}} \mathrm{a}\right]\end{array}$ & $\begin{array}{l}\text { Non- } \\
\text { identical }\end{array}$ \\
\hline $\mathrm{h}$ & $\begin{array}{l}\text { Half-high front vowel [e] at } \\
\text { words ending with voiced } \\
\text { Palatal Nasals consonant }[\mathrm{y}] \text {. } \\
\text { Eg: [yantey] }\end{array}$ & 5 & $\begin{array}{c}75 \\
(100)\end{array}$ & $\begin{array}{l}\text { High front vowel [i] at the end } \\
\text { of words with semi vowel } \\
\text { insertion [ }{ }^{\mathrm{y}} \text { ] followed by low } \\
\left.\text { front vowel [a]. Eg [ranti }{ }^{\mathrm{y}} \mathrm{a}\right]\end{array}$ & $\begin{array}{l}\text { Non- } \\
\text { identical }\end{array}$ \\
\hline $\mathrm{i}$ & $\begin{array}{l}\text { Half-low back vowel [0] at } \\
\text { words ending with voiceless } \\
\text { glottal fricative consonant [h]. } \\
\text { Eg: [bunoh]. }\end{array}$ & 2 & $\begin{array}{c}30 \\
(100)\end{array}$ & $\begin{array}{l}\text { High back vowel }[\mathrm{u}] \text { at words } \\
\text { ending }[\mathrm{h}] \text { with semi vowel } \\
\text { insertion [w] followed by low } \\
\text { front vowel [a]. Eg: [bunuwah] }\end{array}$ & $\begin{array}{l}\text { Non- } \\
\text { identical }\end{array}$ \\
\hline
\end{tabular}


Table 1 (continued)

\begin{tabular}{|c|c|c|c|c|c|}
\hline \multicolumn{6}{|c|}{ Vowel } \\
\hline \multicolumn{2}{|r|}{ A } & \multirow[b]{2}{*}{$\begin{array}{l}\text { No. of } \\
\text { words }\end{array}$} & \multirow[b]{2}{*}{$\begin{array}{l}\text { Say } \\
\text { rate }\end{array}$} & \multirow{2}{*}{\begin{tabular}{l}
\multicolumn{1}{c}{ B } \\
$\begin{array}{l}\text { Minangkabau Language } \\
(\mathrm{MgL})\end{array}$
\end{tabular}} & \multirow{2}{*}{$\frac{\mathrm{C}}{\text { Status }}$} \\
\hline & $\begin{array}{l}\text { Negeri Sembilan Malay } \\
\text { Language (NSML) }\end{array}$ & & & & \\
\hline $\mathrm{j}$ & $\begin{array}{l}\text { Half-low front vowel }[\varepsilon] \text { at } \\
\text { words ending with voiceless } \\
\text { glottal fricative consonant }[\mathrm{h}] \text {. } \\
\text { Eg: [bonch]. }\end{array}$ & 2 & $\begin{array}{c}30 \\
(100)\end{array}$ & $\begin{array}{l}\text { High front vowel [i] at words } \\
\text { ending with glotal fricative }[\mathrm{h}] \\
\text { with semi- vowel }\left[^{\mathrm{y}}\right] \text { insertion } \\
\text { followed by low front vowel [a]. } \\
\left.\text { Eg: [bani }{ }^{\mathrm{y}} \mathrm{ah}\right]\end{array}$ & $\begin{array}{l}\text { Non- } \\
\text { identical }\end{array}$ \\
\hline & \multirow{2}{*}{ Total } & & & Non-identical & 9 \\
\hline & & & & Identical & 1 \\
\hline
\end{tabular}

Note: Numbers in parentheses ( ) is the value of percentage.

Next are the description of the features and examples of the NSML distinctive sounds and its corresponding examples in MgL. This paper uses [ ] for the transcription of sound as practiced by Fromkin, Rodman and Hyams (2007), Yule (1996), and Trudgill (1974).

\section{Final Half-Low Back Vowel [0]}

One of the NSML distinctive features compared to MgL is the existence of words that ended with a half-low back vowel [0]. From the word list tested, there are eight words belonging to this feature. This means, in comparison, in standard Malay (SM) words that end with /a/ is realised in NSML vowel as [0]. The pronunciation test performed found that $99 \%$ of the informants pronounced it in such a way, hence making it the dominant feature of NSML. Data (1) are examples of the sounds.

(1)

$\begin{array}{llll}\text { NSML } & \text { MgL } & \text { SM } & \text { Lexeme } \\ \text { apo } & \text { Apo } & \text { apa } & \text { "what" } \\ \text { du" } 0 & \text { duo } & \text { dua } & \text { "two" } \\ \text { kito } & \text { kito } & \text { kita } & \text { "we" } \\ \text { namo } & \text { namo } & \text { nama } & \text { "name" } \\ \text { sepo } & \text {-na- } & \text { siapa } & \text { "who" }\end{array}$


In contrast to $\mathrm{MgL}$, the vowel at the same position is realised as a half-high back vowel [o]. For example, the word nama "name" in NSML is pronounced as [namo], while in $\mathrm{MgL}$ it is pronounced as [namo].

\section{Initial Half-Low Back Vowel [o]}

Half-low back vowel [0] also exists at the beginning of words in NSML such as [omba?] ombak "wave", [ग1ع?] olek "feast", and [ota?] otak "brain". However, in the word list there is only one word with this feature, that is, [oyan] orang "person". In comparison, standard Malay words preceded by half-high back vowel [o], is realised by a half-low back vowel [0] in NSML. In MgL, the vowel sound at the same position is realised as a high-back vowel [u]. Thus, the word orang is pronounced as [uran].

\section{Initial Open Syllable Half-Low Back Vowel [ə]}

NSML also shows the existence of half-low back vowel [0] at the beginning of open syllables. In the word list, there are 27 words that fall within this category and a total of $89 \%$ (361 times) was pronounced with vowel feature [0]. This means that, in comparison, in standard Malay words at the same position is schwa or [ə], in the NSML is realised as [0]. For example, beras and kepala in SM are pronounced as [boych] and [kəpalo] in NSML.

In MgL, vowel at the same position in the same words was realised as low front vowel [a]. Thus, the words beras and kepala in $\mathrm{MgL}$ are pronounced as [bareh] and [kapalo] respectively.

\begin{tabular}{|c|c|c|c|}
\hline NSML & $\mathrm{MgL}$ & SM & Lexeme \\
\hline boych & barch & beras & "rice" \\
\hline bosa & -na- (gadang) & besar & "big" \\
\hline сэрє? & сарє? & cepat & "fast" \\
\hline robu'h & $\mathrm{abu}^{\mathrm{y}} \mathrm{h}$ & rebus & "boill" \\
\hline koci? & kaci $^{y} a ?$ & kecil & "small" \\
\hline lomang & laman & lemang & "glutinous rice cooked in bamboo" \\
\hline lopeh & lapeh & lepas & "escape" \\
\hline sobot & sabuyi? & sebut & "say" \\
\hline toyobay & tabay & terbang & "fly" \\
\hline toyuh & $\operatorname{taru}^{y}$ ih & terus & "direct" \\
\hline
\end{tabular}




\section{Half-Low Front Vowel [ع] in Close Ended Words}

This study also found the existence of a half-low front vowel $[\varepsilon]$ at the end of closed words in the NSML. Through nine related words in the wordlist it was found that $97 \%$ (131 times) when the vowel is at the end of closed words, it is pronounced as such. This means that the low front vowel [a] in standard Malay language at the same position is realised as $[\varepsilon]$ in NSML. This sound, at the same position also occurred in $\mathrm{MgL}$. This is the first identical phonology characteristic between the two languages. Data (3) are examples in both the languages.

(3)

\begin{tabular}{|c|c|c|c|}
\hline NSML & $\mathrm{MgL}$ & SM & Lexeme \\
\hline cэpe? & cape? & cepat & "fast" \\
\hline ompe? & ampe? & empat & "four" \\
\hline lokch & lakch & lekas & "fast" \\
\hline lompe? & lompe? & lompat & “jump” \\
\hline sompe? & -na- (kale?) & sempat & "having time to" \\
\hline
\end{tabular}

\section{Half-High Back Vowel [o] in Words Ending with Voiceless Dental-Alveolar Consonant [t]}

In standard Malay language, words which end with voiceless dental-alveolar consonant [t], the previous sound is a high-back vowel $[\mathrm{u}]$. But for NSML, the related sound is realised as the half-high back vowel [o]. This is proven by five related words which appear in the test register. This sound was pronounced $100 \%$ (75 appearances) as [o].

$\begin{array}{llll}\text { NSML } & \text { MgL } & \text { SM } & \text { Lexeme } \\ \text { yambot } & \text { rambui? } & \text { rambut } & \text { "hair" } \\ \text { lutot } & \text { lutui? } & \text { lutut } & \text { "knee" } \\ \text { sobot } & \text { sabui? } & \text { sebut } & \text { "say" } \\ \text { mulot } & \text { mului? } & \text { mulut } & \text { "mouth" } \\ \text { pyyot } & \text { parui? } & \text { perut } & \text { "stomach" }\end{array}$


It is different in $\mathrm{MgL}$, sounds at the same position in the words tested are diphthongs [ui] and ended with a glottal [?] instead of [t]. Thus, the word mulut "mouth" for example, in NSML is pronounced as [mulot], in MgL it is pronounced as [mului?].

\section{Half-High Back Vowel [o] in words Ending with Voiced Nasal Palatal Consonant $[\eta]$}

The half-high back vowel [o] also occurs in words ending with nasal palatal consonants [ $\mathrm{g}$ ] in NSML. For example, the words [kampon] "village" in the pronunciation test, 99\% (89 times) of the pronounciation of the 6 words were pronounced as such. As a comparison, in standard Malay language, the phoneme at the same position is a high back vowel [u].

\begin{tabular}{|c|c|c|c|}
\hline NSML & $\mathrm{MgL}$ & SM & Lexeme \\
\hline kampon & kampu'way & kampung & "village" \\
\hline idon & iduway & hidung & "nose" \\
\hline gantoy & gantuway & gantung & "hang" \\
\hline janton & jantu'wan & jantung & "heart" \\
\hline junjōon & jujŭwav & junjung & "carrying on the head" \\
\hline
\end{tabular}

In contrast to $\mathrm{MgL}$, sounds at the same position is the high-back vowel $[\mathrm{u}]$ but with semi vowel insertion [w] followed by the low-front vowel [a]. Thus, the word kampung and jantung were each pronounced as [kampuwaj] and [jantuwan].

\section{Half-High Front Vowel [e] at the End of Open Ended Words}

NSML shows the existence of words that end with mid-high front vowel [e] at the end of open words, such as [ae] air "water". In the test of this research, there were three words in this category and were pronounced $100 \%$ (45 appearances) with [e]. In comparison, words ending with cluster [ir] in standard Malay, were realised as [e] in NSML.

However, in MgL the [ir] cluster is realised with a high-front vowel [i], followed by the semi vowel insertion vocal $\left.{ }^{\mathrm{y}}\right]$ and concluded with the low-front vowel [a]. Thus, air is pronounced [ai $\left.{ }^{\mathrm{y}} \mathrm{a}\right]$. The following are examples relevant to both languages. 
(6)

$\begin{array}{llll}\text { NSML } & \text { MgL } & \text { SM } & \text { Lexeme } \\ \text { ae } & \text { ai }^{y} a & \text { air } & \text { "water" } \\ \text { bibe } & \text { bibi }^{y} \text { a } & \text { bibir } & \text { "lips" } \\ \text { pase } & \text { pasi }^{y} a & \text { pasir } & \text { "sand" }\end{array}$

\section{Half-High Front Vowel [e] in Words Ending with Voiced Nasal Palatal Consonant [n]}

NSML also has mid-high front vowel [e] in words ending with voiced nasal palatal consonant [y]. For example, [yantey] ranting "branch" and [dagen] daging "meat". In the test wordlist, there are five words with this feature. The sounds of these five words were pronounced $100 \%$ with [e] by all informants. In other words, words spelled with the phoneme /i/ in standard Malay at this position, is realised by the mid-high front vowel [e] in the NSML. These are the words.

\begin{tabular}{|c|c|c|c|}
\hline NSML & $\mathrm{MgL}$ & SM & \\
\hline anǰen & anjì $i^{y}$ ay & anjing & “dog" \\
\hline bayen & bari'ay & baring & "lie down" \\
\hline dagen & dagi $^{\mathrm{y}} a \eta$ & daging & "meat" \\
\hline kuney & kuniyan & kuning & "yellow" \\
\hline yantey & rantiªn & ranting & "tree branch" \\
\hline
\end{tabular}

However, for MgL, sounds at the same position is pronounced with a high front vowel [i] with semi vowel insertion $\left[{ }^{\mathrm{y}}\right]$ and followed by the low front vowel [a]. Examples can be seen in the list above.

\section{Half-low Back Vowel [o] in Words Ending with Voiceless Glottal Fricative Consonant [h]}

A half-low back vowel [0] was also found before the voiceless glottal fricative consonant $[\mathrm{h}]$ at the end of words, such as [ponoh] penuh "full". This means that, in standard Malay language, words ending with phoneme $[\mathrm{h}]$, the previous phoneme is [u], but in NSML, the sound is realised as a mid-low back vowel [0]. In the list of test words, there are only two words with this feature, however, 100\% (30 appearances) were pronounced as such. 
(8)

$\begin{array}{llll}\text { NSML } & \text { MgL } & \text { SM } & \text { Lexeme } \\ \text { bunoh } & \text { bunuwah } & \text { bunuh } & \text { "kill" } \\ \text { ponoh } & \text { panuwah } & \text { penuh } & \text { "full" }\end{array}$

However, this phonological feature does not exist in MgL. In MgL, the presence of high back vowel $[\mathrm{u}]$ with semi vowel insertion $[\mathrm{w}]$ is followed by a low front vowel [a], such as listed above.

\section{Half-Low Front Vowel [ع] in Words Ending with Voiceless Glottal Fricative Consonant [h]}

In standard Malay language, there are words with the phoneme $/ \mathrm{i}$ / in words ending with a voiceless glottal fricative $[\mathrm{h}]$ such as benih "seed". But in the NSML, the phoneme is realised as a mid-low front vowel $[\varepsilon]$, such as [bonch]. There is only one word with this feature in the test register and pronounced as $[\varepsilon] 100 \%(15$ times). It is articulated in initial syllables with the back vowel [0]. Both [0] and $[\varepsilon]$ are the mid-low vowels. This is in contrast with the word putih "white" for example, which is pronounced as [puteh], not "[putch]. This is because [u] and [c] are not harmony vowels in terms of size of the articulation aperture. Each is a high and mid-low vowel respectively.

In $\mathrm{MgL}$, the phonological realisation is the existence of high front vowel [i] which is then inserted in the semi vowel [y] and low front vowel [a]. Thus, benih "seed" is pronounced as [bani $\left.{ }^{\mathrm{y}} \mathrm{ah}\right]$.

$\begin{array}{llll}\text { NSML } & \text { MgL } & \text { SM } & \text { Lexeme } \\ \text { boneh } & \text { baniyah } & \text { benih } & \text { "seed" }\end{array}$

Final Voiceless Glottal Fricative Consonant [h] Preceded by Mid-Low Front Vowel $[\varepsilon]$

In NSML, words ending with voiceless glottal fricative consonant $[\mathrm{h}]$ are preceded by the mid-low front vowel $/ \varepsilon /$ as in [lopeh] lepas "escape". In the test, there are five words with this feature and $95 \%$ was pronounced by the informants. The relevant words are shown in Data (10). As a comparison, in standard Malay, such words ended with [s] and proceeded with the low front vowel [a]. The same phonological feature apparently also occurs in MgL. This is the second identical phonological feature between the two languages. 
(10)

$\begin{array}{llll}\text { NSML } & \text { MgL } & \text { SM } & \text { Lexeme } \\ \text { boych } & \text { barch } & \text { beras } & \text { "rice" } \\ \text { kipch } & \text { kipch } & \text { kipas } & \text { "fan" } \\ \text { lokeh } & \text { lakch } & \text { lekas } & \text { "fast" } \\ \text { lopeh } & \text { lapeh } & \text { lepas } & \text { "escape" } \\ \text { panch } & \text { panch } & \text { panas } & \text { "hot" }\end{array}$

Table 2: Comparison of the NSML consonant features with MgL according to position in words

\begin{tabular}{|c|c|c|c|c|c|}
\hline \multicolumn{6}{|c|}{ Consonant } \\
\hline & A & & & B & $\mathrm{C}$ \\
\hline & $\begin{array}{l}\text { Negeri Sembilan Malay } \\
\text { Language (NSML) }\end{array}$ & $\begin{array}{l}\text { No. of } \\
\text { words }\end{array}$ & $\begin{array}{l}\text { Say } \\
\text { rate }\end{array}$ & $\begin{array}{l}\text { Minangkabau Language } \\
(\mathrm{MgL})\end{array}$ & Status \\
\hline $\mathrm{k}$ & $\begin{array}{l}\text { Final voiceless glottal fricative } \\
\text { consonant }[\mathrm{h}] \text { proceeded by } \\
\text { half-low front vowel }[\varepsilon] \text { or } \\
\text { high front vowel }[\mathrm{i}] \text {. } \\
\text { Eg: [lopsh], [nipih] }\end{array}$ & 5 & $\begin{array}{c}71 \\
(95)\end{array}$ & $\begin{array}{l}\text { Final voiceless glottal } \\
\text { fricative consonant [h] } \\
\text { proceeded by semi- low } \\
\text { front vowel } / \varepsilon / . \text { Eg: [lapsh] }\end{array}$ & Identical \\
\hline 1 & 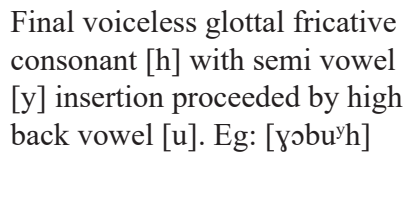 & 3 & $\begin{array}{c}45 \\
(100)\end{array}$ & $\begin{array}{l}\text { Final voiceless glotal } \\
\text { fricative con-sonant }[\mathrm{h}] \\
\text { with semi-vowel }[\mathrm{y}] \text { and } \\
\text { high front vowel }[\mathrm{i}] \text { insertion. } \\
\text { Eg: }\left[\mathrm{abu}^{\mathrm{y}} \mathrm{h}\right]\end{array}$ & $\begin{array}{l}\text { Non- } \\
\text { identical }\end{array}$ \\
\hline $\mathrm{m}$ & $\begin{array}{l}\text { Initial voiced palatal fricative } \\
\text { consonant }[\gamma] . \text { Eg: [yamay] }\end{array}$ & 4 & $\begin{array}{c}60 \\
(100)\end{array}$ & $\begin{array}{l}\text { Initial voiced dental-alveolar } \\
\text { fricative consonant }[\mathrm{r}] \text {. } \\
\text { Eg: }[\text { rame] }\end{array}$ & $\begin{array}{l}\text { Non- } \\
\text { identical }\end{array}$ \\
\hline $\mathrm{n}$ & $\begin{array}{l}\text { Non-existance of dental- } \\
\text { alveolar fricative consonant [r] } \\
\text { at the end of words. Eg: [tolo], } \\
\text { [bibe] }\end{array}$ & 11 & $\begin{array}{l}162 \\
(98)\end{array}$ & $\begin{array}{l}\text { Non-existance of dental- } \\
\text { alveolar fricative consonant } \\
\text { [r] at the end of words, but } \\
\text { having low-front vowel [a] } \\
\left.\text { and insertion }\left[^{\mathrm{w}}\right] \text { or }{ }^{\mathrm{y}}\right] \text {. } \\
\text { Eg: }\left[\text { talu }^{\mathrm{w}} \mathrm{a}\right]\end{array}$ & $\begin{array}{l}\text { Non- } \\
\text { identical }\end{array}$ \\
\hline o & $\begin{array}{l}\text { Final glottal consonant [?] } \\
\text { proceeded by half-low front } \\
\text { vowel }[\varepsilon] . \text { Eg: [ompe?] }\end{array}$ & 5 & $\begin{array}{c}75 \\
(100)\end{array}$ & $\begin{array}{l}\text { Final glottal consonant [?] } \\
\text { proceeded by half-low front } \\
\text { vowel }[\varepsilon] . \text { Eg: }[\operatorname{amp} \varepsilon ?]\end{array}$ & Identical \\
\hline $\mathrm{p}$ & $\begin{array}{l}\text { Existence of final voiceless } \\
\text { plosive alveolar consonant }[\mathrm{t}] \\
\text { that preceded the front half- } \\
\text { high vowel [e]. Eg:[kulet] }\end{array}$ & 2 & $\begin{array}{c}30 \\
(100)\end{array}$ & $\begin{array}{l}\text { Non-existence of final } \\
\text { voiceless plosive alveolar } \\
\text { consonant [t], but glottal [?] } \\
\text { exists preceded by high front } \\
\text { vowel [i]. Eg: [kuli?] }\end{array}$ & $\begin{array}{l}\text { Non- } \\
\text { identical }\end{array}$ \\
\hline
\end{tabular}


Table 2 (continued)

\begin{tabular}{|c|c|c|c|c|c|}
\hline \multicolumn{6}{|c|}{ Consonant } \\
\hline \multicolumn{2}{|r|}{ A } & \multirow[b]{2}{*}{$\begin{array}{l}\text { No. of } \\
\text { words }\end{array}$} & \multirow[b]{2}{*}{$\begin{array}{l}\text { Say } \\
\text { rate }\end{array}$} & \multirow{2}{*}{$\begin{array}{l}\text { B } \\
\begin{array}{l}\text { Minangkabau Language } \\
(\mathrm{MgL})\end{array}\end{array}$} & \multirow{2}{*}{$\frac{\mathrm{C}}{\text { Status }}$} \\
\hline & $\begin{array}{l}\text { Negeri Sembilan Malay } \\
\text { Language (NSML) }\end{array}$ & & & & \\
\hline q & $\begin{array}{l}\text { Non-existence of initial } \\
\text { voiceless glottal fricative } \\
\text { consonant [h]. Eg: [idon] }\end{array}$ & 5 & $\begin{array}{c}69 \\
(92)\end{array}$ & $\begin{array}{l}\text { Non-existence of initial } \\
\text { voiceless glottal fricative } \\
\left.\text { consonant }[\mathrm{h}] . \text { Eg: : }\left[\mathrm{idu}^{\mathrm{w}} \mathrm{a}\right]\right]\end{array}$ & Identical \\
\hline \multirow{2}{*}{\multicolumn{2}{|c|}{ Total }} & & & Non-identical & 14 \\
\hline & & & & Identical & 3 \\
\hline
\end{tabular}

Note: Numbers in parentheses () is the value of percentage.

Final Voiceless Glottal Fricative Consonant [h] with Semi Vowel [y] Insertion Preceded by a High Back Vowel [u]

Another phonological feature that shows the uniqueness and identity of NSML when compared with $\mathrm{MgL}$ is the presence of voiceless glottal fricative consonant $[\mathrm{h}]$ at the end of words preceded by a semi vowel insertion $\left.{ }^{\mathrm{y}}\right]$ and a high back vowel $[\mathrm{u}]$, as in $\left[\mathrm{\gamma}^{\circ} \mathrm{bu}^{\mathrm{y}} \mathrm{h}\right]$ "rebus". In the test word glossary there are three words of this category, with $100 \%$ (45 times) pronouncing with this feature. This means, the phonology feature of words in this category is the realisation of dental-alveolar fricative consonant $[\mathrm{s}]$ at the end of words preceded by the high back vowel $[\mathrm{u}]$ in standard Malay language. $\mathrm{In} \mathrm{MgL}$, the voiceless glottal fricative consonant [h] is also at the end of such words, it is however, preceded by the diphthongs [ui].

$\begin{array}{llll}\text { NSML } & \text { MgL } & \text { SM } & \text { Lexeme } \\ \text { gobuyh } & \text { Abuih } & \text { rebus } & \text { "boil" } \\ \text { kuyuyh } & \text { kuruih } & \text { kurus } & \text { "thin" } \\ \text { toyu'h } & \text { taruih } & \text { terus } & \text { "direct" }\end{array}$

\section{Initial Voiced Palatal Fricative Consonant [y]}

This study also found the existence of voiced palatal fricative consonant $[\gamma]$ at the beginning of words in NSML. There are four words of this category in the wordlist, Data (12). This means that dental alveolar fricative $[\mathrm{r}]$ at the beginning of words in standard Malay is realised as a voiced palatal fricative [y] in NSML. About $100 \%$ (60 times) it is pronounced as [y] by the informants. In the MgL, sounds at the beginning of words is realised as [r] as well or it is silent. 


$\begin{array}{llll}\text { NSML } & \text { MgL } & \text { SM } & \text { Lexeme } \\ \text { yamay } & \text { rame } & \text { ramai } & \text { "many people" } \\ \text { yambot } & \text { rambui? } & \text { rambut } & \text { "hair" } \\ \text { yantey } & \text { rantian } & \text { ranting } & \text { "branch" } \\ \text { yobuyh } & \text { abuih } & \text { rebus } & \text { "boil" }\end{array}$

\section{Non-Existance of Final Dental-Alveolar Fricative Consonant [r]}

The dental-alveolar fricative consonant $[\mathrm{r}]$ is not found at the end of words in NSML. This means words which ended with the vibration sound $[\mathrm{r}]$ in standard Malay is not present in NSML. In the word list tested, there are 11 related words and 98\% (162 times) did not pronounce the dental-alveolar sound at the end of words. For example tidur "sleep" and leher "neck" are pronounced as [tido] and [lehe].

Compared to MgL, the [r] also does not exist at the end of words, but ended with a low front vowel [a] with half vowel insertion $\left.{ }^{\mathrm{w}}\right]$ or $\left.{ }^{\mathrm{y}}\right]$ and subject to the preceding vowel. Following are the words and its pronunciation in both languages.

\begin{tabular}{|c|c|c|c|}
\hline NSML & $\mathrm{MgL}$ & $\mathrm{SM}$ & Lexeme \\
\hline ae & $\mathrm{ai}^{\mathrm{y}} \mathrm{a}$ & air & "water" \\
\hline bibe & bibi $^{\mathrm{y}} \mathrm{a}$ & bibir & "lips" \\
\hline عko & $\mathrm{iku}^{\mathrm{w} a}$ & ekor & "tail" \\
\hline lehe & li $^{y_{1}}$ & leher & "neck" \\
\hline pase & pasi $^{\mathrm{y} a}$ & pasir & "sand" \\
\hline tolo & talu ${ }^{\mathrm{w}} \mathrm{a}$ & telur & "egg" \\
\hline
\end{tabular}

\section{Final Glottal [?] Preceded by Mid-Low Front Vowel [ $\varepsilon$ ]}

This study also found the existence of the glottal stop sound [?] at the end of closed

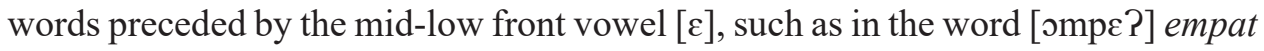
"four". There are five words of this category in the test register, with all or $100 \%$ (75 times) pronounced this feature. In comparison, in standard Malay language, these words are spelled and ended with dental-alveolar stop consonant $[t]$ which is preceded by the low front vowel [a]. The same phonological feature occurs in MgL. This is the third identical phonology feature for both languages. 


\begin{tabular}{|c|c|c|c|}
\hline NSML & $\mathrm{MgL}$ & SM & Lexeme \\
\hline bule? & bule? & bulat & "round" \\
\hline сэрє? & сарє? & cepat & "fast" \\
\hline ompe? & ampe? & empat & "four" \\
\hline lompe? & lompe? & lompat & “jump” \\
\hline somp $\varepsilon$ ? & -na- & sempat & "having time to" \\
\hline
\end{tabular}

\section{The Existence of Final Voiceless Plosive Alveolar Consonant [t] Preceded by a Mid-High Front Vowel [e]}

Another unique phonological feature of NSML compared to MgL is the existence of a voiceless alveolar consonant [ $t$ ] at the end of words which is preceded by a mid-high front vowel [e], such as [buket] "hill". However, in the test glossary, there are only two words with this feature, but $100 \%$ was pronounced as such. This phonological feature is similar with standard Malay language, but the preceding sound is a high front vowel [i].

On the other hand, this feature does not occur in MgL. In MgL, such final sounds are realised with glottal [?] and the preceding vowel is the front high vowel [i], such as [buki?].

$\begin{array}{llll}\text { NSML } & \text { MgL } & \text { SM } & \text { Lexeme } \\ \text { buket } & \text { buki? } & \text { bukit } & \text { "hill" } \\ \text { kulet } & \text { kuli? } & \text { kulit } & \text { "skin" }\end{array}$

\section{Non-Existence of Initial Voiceless Glottal Fricative Consonant [h]}

Finally, the study also found that NSML did not have initial voiceless glottal fricative consonant sound $[\mathrm{h}]$ that is present in standard Malay language. For example, hijau "green" is pronounced as [ijau]. There are five words with this feature in the wordlist and $92 \%$ were pronounced as such by the informants. Similar phonological feature was also found in MgL. This is the fourth identical phonology characteristic between the two languages. Pronunciation of the words is shown in Data (16). 


$\begin{array}{llll}\text { NSML } & \text { MgL } & \text { SM } & \text { Lexeme } \\ \text { abo? } & \text {-na- } & \text { habuk } & \text { "ash" } \\ \text { ati } & \text { ati } & \text { hati } & \text { "liver" } \\ \text { idoy } & \text { iduway } & \text { hidung } & \text { "nose" } \\ \text { ijau } & \text { ijau } & \text { hijau } & \text { "green" } \\ \text { itam } & \text { itam } & \text { hitam } & \text { "black" }\end{array}$

Based on the discussion above, a feature which is very prominent in NSML is the non-existence of dental-alveolar fricative consonant $[\mathrm{r}]$ or rhotic, either at the initial, middle, or final positions of words. In initial and middle positions of words, such a phonology feature is realised with palatal fricative [y]. On the contrary, rhotic is very dominant in the initial and middle position of words in MgL.

\section{DISCUSSION}

Based on the findings, it can be concluded that NSML phonology has a distinctive identity that distinguishes it from MgL. Countervailing the close relationship of language with identity development, identity based on phonology is also an integral part of Negeri Sembilan's identification as one of the community's languages. Linguistics is a practical and relevant cultural trait and practice in identifying Negeri Sembilan speakers. However, other cultural practices (such as the Perpatih social system) is influenced by foreign culture. It is clear in the context of Negeri Sembilan, linguistic ability is a significant and overt identity marker that is easily found in the practices of daily life because everyone speaks the language. This is in line with Wardhaugh and Fuller's $(2015,72)$ contention who claimed that "identity is not something you have, it is something you $d o$ ". However, this is different in the case of the Perpatih custom which has long been associated as the identity of Negeri Sembilan speakers. Although the custom is overtly practised, it is not observed on a daily basis unlike the NSML which is used in daily communication. Customary practices can only be identified when there is a ceremony and ritual such as the appointment of the head of customs, engagement or marriage.

As discussed earlier at the beginning of this article, we state that language and identity could not be separated. The concept of identity adopted in this article is based on Wardhaugh and Fuller (2015), where identity is reflected through various linguistics aspects. Hence, this study has chosen phonological aspects to foreground the identity of a speaker and based on the findings, significant distinctive features of NSML have proven that NSML is distinct from MgL. 
The issue of unique features of phonology that form the state's identity could actually be traced back to over 65 years ago through a study on NSML phonology by Hendon (1966). She conducted her field study in 1951 on a 60 year old female speaker of the Biduanda clan. Biduanda is a clan of local descent. Hendon (1966, xiii) stated "However, the Negri Sembilan dialect is by no means identical with the best-known contemporary dialect of Minangkabau, and stands in some respects closer to standard Malay than to Minangkabau".

It is clear that Hendon's phonological analysis at that time does have NSML features, although there are some variations in transcription symbols used. For example, we use [0] and [e] for mid-low back and mid-high front vowels; Hendon (1966) used the symbols [a] and [i] respectively, see Data (17). Those are just a selection of the symbols, but it still shows the NSML sound features, rather than $\mathrm{MgL}$ sounds. In our opinion, the transcription of some sound symbols' variation is common in linguistics. Hendon is a Western scholar who was newly exposed to this language, whereas our transcription is in line with other local researchers.

$\begin{array}{llll}\text { Hendon (1966) } & \text { Ours } & \text { SM } & \text { Lexeme } \\ \text { ai } & \text { ae } & \text { air } & \text { "water" } \\ \text { ampeq } & \text { ompe? } & \text { empat } & \text { "four" } \\ \text { gigit } & \text { giget } & \text { gigit } & \text { "bite" } \\ \text { kabaw } & \text { kobau } & \text { kerbau } & \text { "buffalo" } \\ \text { laykap } & \text { loykap } & \text { lengkap } & \text { "complete" } \\ \text { pai } & \text { poi } & \text { pergi } & \text { "go" } \\ \text { panēh } & \text { panch } & \text { panas } & \text { "hot" } \\ \text { piwq } & \text { pi } & \text { periuk } & \text { "pot" } \\ \text { sadap } & \text { sodap } & \text { sedap } & \text { "delicious" }\end{array}$

\section{CONCLUSION}

Long before the arrival of western explorers, inter-province population mobility in the Malay Archipelago was commonplace. The migration of the Minangkabaus to the Malay Peninsula, especially to where it is now known as Negeri Sembilan resulted in the close contact with the local population (Reniwati, 2012). In addition to cultural contact, language contact also took place followed by assimilation and evolution with the locals and its surrounding neighbour's language, which eventually after hundreds of years emerged as one of the Malay language varieties named NSML. In terms of the language spread theory, NSML and MgL are from 
the proto-language family, which is Malay (Nothofer 1988), and is also in the Austronesia cluster.

NSML has been intensively studied. However, most of the studies were conducted within the linguistic dimension, with only a few that examined the extralinguistic dimension. This study has looked at NSML within the extra-linguistic dimension but focuses on identity values. This synchronic study has shown that NSML has distinctive phonological features. A large part of its features are distinct from the language that it is often associated with, namely MgL. Thus, this finding concludes that NSML has its own identity. Negeri Sembilan has indeed accepted, adopted and practised the Minangkabau culture, namely Perpatih custom, but not its language. Thus, the stereotypical notion that NSML is similar with MgL should be dismissed.

The main contribution of this study is the findings of the 17 distinctive phonological features in NSML which are different from MgL. The findings are based on the pronunciation of native speakers of both languages. However, the data for $\mathrm{MgL}$ in this study is only confined to east Sumatra. Further studies on phonological aspects in MgL should be conducted and cover a wider area, such as North Sumatra. MgL is also the lingua franca in North Sumatera. Hence, the data on MgL would be more representative for it to be compared with NSML.

\section{ACKNOWLEDGEMENTS}

This paper resulted from research project coded FRGS/2/2014/SSI01/UKM/01/1 funded by Ministry of Higher Education, Malaysia.

\section{REFERENCES}

Abdullah Siddik. 1975. Pengantar undang-undang adat di Malaysia. Kuala Lumpur: Penerbit Universiti Malaya.

Ajid Che Kob. 2002. Dialek Melayu Negeri Sembilan: Beberapa aspek linguistik. In Menelusuri jejak Melayu-Minangkabau, eds. Mochtar Naim, Zulqaiyyim, Hasanuddin and Gusdi Sastera, 145-157. Padang: Yayasan Citra Budaya Indonesia.

Amat Juhari Moain. 2002. Hubungan Melayu-Minangkabau dari sudut sejarah, bahasa, sastera, budaya, dan masyarakat. In Menelusuri jejak Melayu-Minangkabau, eds. Mochtar Naim, Zulqaiyyim, Hasanuddin and Gusdi Sastera, 19-43. Padang: Yayasan Citra Budaya Indonesia. 
Arbak Othman. 1994. Fonologi dialek Negeri Sembilan: Satu teknik pengesanan kosa kata untuk tfksikografi [sic] standard. In Negeri Sembilan, gemuk dipupuk, segar bersiram: Adat merentas zaman, eds. A. Samad Idris, Norhalim Ibrahim Muhammad Tainu and N.S. Dharmala. Negeri Sembilan: Jawatankuasa Penyelidikan Budaya Negeri Sembilan.

Asmah Haji Omar. 1985. Susur galur Bahasa Melayu. Kuala Lumpur: Dewan Bahasa dan Pustaka.

Chambers, J.K. and P. Trudgill. 1980. Dialectology. Cambridge: Cambridge University Press.

Crystal, D. 2003. The Cambridge encyclopedia of language. 2nd ed. Cambridge: Cambridge University Press.

De Jong, J.P.E. 1952. Minangkabau and Negri Sembilan: Socio-political structure in Indonesia. The Haque: Martinus Nijhoff.

Fairclough, N. 2003. Analysing discourse: Textual analysis for social research. London and New York: Routledge. https://doi.org/10.4324/9780203697078

Fitzgerald, C.P. 1966. The concise history of East Asia. Hong Kong: Heinemann Educational Book Asia Ltd.

Fromkin, V., R. Rodman and N. Hyams. 2007. An introduction to language. 8th ed. Boston: Thomson.

Hendon, R.S. 1966. The phonology and morphology of Ulu Muar Malay (Kuala Pilah District, Negeri Sembilan, Malaya). New Haven: Yale University.

Ibrahim Mustapa and Ibrahim Daud. 1990. Analisis dialek daerah Kuala Pilah daripada aspek fonologi. Jurnal Dewan Bahasa December: 975-982.

Idris Aman. 2014. Dialek sosial. In Variasi bahasa, eds. Idris Aman and Mohammed Azlan Mis, 39-55. Bangi, Selangor: Penerbit UKM.

Idris Aman, Mohammad Fadzeli Jaafar and Norsimah Mat Awal. 2015. Bahasa Negeri Sembilan: Keunikan, sikap dan kefahaman. Bangi, Selangor: Penerbit UKM.

Idris Aman, Norsimah Mat Awal, Mohammad Fadzeli Jaafar and Rikha Permata Sari. 2014. Dialek Negeri Sembilan, kebolehfahaman kata usang dan perubahan sosial. In Variasi bahasa, eds. Idris Aman and Mohammed Azlan Mis, 118-152. Bangi, Selangor: Penerbit UKM.

Jabatan Kemajuan Orang Asli (JAKOA) Malaysia. 2016. Portal rasmi JAKOA. http:// www.jakoa.gov.my/ (accessed 6 January 2016).

Jamaludin Samsudin. 1999. Dialek Negeri Sembilan - satu pandangan. Warisan: Jurnal Persatuan Sejarah Malaysia Cawangan Negeri Sembilan 22: 46-57.

Kramsch, C. 1998. Language and cultural identity. Oxford: Oxford University Press.

Labov, W. 1972. Sociolinguistics patterns. Philadelphia: University of Pennsylvania Press.

Le Page, R.B. and A. Tabouret-Keller. 1985. Act of identity: Creol-based approaches to ethnicity and language. Cambridge: Cambridge University Press.

Leary, M.R. and J.P. Tangney. 2003. Handbook of self and identity. New York: Guilford Press.

Media Sandra Kasih. 2002. Sistem sapaan kekeluargaan bahasa Minangkabau dan bahasa Melayu Malaysia. In Menelusuri jejak Melayu-Minangkabau, eds. Mochtar Naim, Zulqaiyyim, Hasanuddin and Gusdi Sastera, 123-130. Padang: Yayasan Citra Budaya Indonesia. 
Milroy, L. 1987. Language and social networks. 2nd ed. Oxford: Basil Blackwell.

Mohd Faiz Burhanuddin. 1998. Kajian dialek Negeri Sembilan. Warisan: Jurnal Persatuan Sejarah Malaysia Cawangan Negeri Sembilan 21: 54-67.

Mohd Pilus Yunus. 1978. Bahasa Negeri Sembilan dan dialek umum bahasa Melayu: Suatu perbandingan dari sudut fonologi. Dewan Bahasa, 8, 586-597.

Norsimah Mat Awal and Nur Liyana Zulkffle. 2011. Pendeskripsian makna kata kerja aktiviti dialek Negeri Sembilan. Simposium Kebudayaan Indonesia-Malaysia Ke12 (SKIM XII), Universiti Kebangsaan Malaysia, Selangor. 29-30 November.

Norsimah Mat Awal, Idris Aman and Mohammad Fadzeli Jaafar. 2013. Attitude, understanding and identity of Negeri Sembilan Malay Dialect Speakers. Pertanika Journal of Social Sciences \& Humanities 21(S): 99-118.

Norsimah Mat Awal, Mohammad Fadzeli Jaafar and Nur Liyana Zulkffle. 2014. Variasi semantik kata kerja perbuatan dalam dialek Negeri Sembilan. In Variasi bahasa, eds. Idris Aman and Mohammed Azlan Mins. Bangi, Selangor: Penerbit UKM.

Nordin Selat. 1982. Sistem sosial Adat Perpatih. Kuala Lumpur: Utusan Publications \& Distributions Sdn. Bhd.

Nothofer, B. 1988. A discussion of two Austronesian subgroups: Proto-Malay and protoMalayic. In Rekonstruksi dan cabang-cabang Bahasa Melayu induk, eds. Mohd. Thani Ahmad and Zaini Mohamed Zain, 34-58. Kuala Lumpur: Dewan Bahasa dan Pustaka.

Phillipson, R. 1992. Linguistic imperialism. Oxford: Oxford University Press.

Rahilah Omar and Nelmawarni. 2008. Negeri Sembilan: Rantau Minangkabau di Semenanjung Tanah Melayu. Historia: Journal of Historical Studies IX(2): 2-30.

Ramli Md. Saleh. 2002. Sintaksis dialek Negeri Sembilan. In Menelusuri jejak MelayuMinangkabau, eds. Mochtar Naim, Zulqaiyyim, Hasanuddin and Gusdi Sastera, 139-144. Padang: Yayasan Citra Budaya Indonesia.

Reniwati. 1990. Bahasa Minangkabau dan dialek Negeri Sembilan dalam perbandingan fonemis. Andalas: Jurnal Penelitian dan Pengabdian pada Masyarakat. No. 5 (September): 74-83.

2012. Bahasa Minangkabau dan dialek Negeri Sembilan: Satu tinjauan perbandingan linguistik historis komparatif. Wacana Etnik: Jurnal Ilmu Sosial dan Humaniora 3(1): 71-86.

Reniwati and Ab. Razak Ab. Karim. 2015. Kata sapaan separa rasmi dalam masyarakat Minangkabau di Kabupaten 50 Kota dan daerah Rembau: Suatu kajian perbandingan. International Journal of the Malay World and Civilisation 3(2): 63-70.

Reniwati, Midawati and Noviatri. 2017. Lexical variations of Minangkabau language within West Sumatra and Peninsular Malaysia: A dialectology study. Geografia Online Malaysia Journal of Society and Space 13(3): 1-10. https://doi.org/10.17576/ geo-2017-1303-01

Sharifah Raihan Syed Jaafar. 2017. Pembentukan struktur suku kata dialek Melayu Kuala Pilah. Jurnal Bahasa 17(1): 61-83.

Sharman Abu. 1973. Satu tinjauan ringkas tentang bunyi-bunyi vokal dalam dialek Negeri Sembilan. Dewan Bahasa, December, 559-566. 
1974. Sistem bunyi konsonan dalam dialek Negeri Sembilan. Dewan Bahasa, June, 277-286.

Tabouret-Keller, A. 1997. Language and identity. In The handbook of sociolinguistics, ed. F. Coulmas, 315-326. Oxford: Blackwell.

Trudgill, P. 1974. The social differentiation of English in Norwich. Cambridge: Cambridge University Press.

Wardhaugh, R. and J.M. Fuller. 2015. An introduction to sociolinguistics. 7th ed. West Sussex: Wiley Blackwell.

Wikipedia. n.d. Swadesh list 1971. https://en.wikipedia.org./wiki/Swadesh_list. (accessed 21 January 2015).

Winstedt, R.O. 1934. Negri Sembilan: The history, polity and beliefs of the nine states. JMBRAS 12(3) October: 35-111.

Yeop Johari Yaakob. 1984. Analisis fonem Bahasa Melayu dialek Negeri Sembilan. Dewan Bahasa, August, 506-528.

. 1986. Pemakaian kosa kata Bahasa Melayu dialek Negeri Sembilan dalam kehidupan masyarakat desa. Dewan Bahasa, September, 663-689.

1989. Dialek Melayu Negeri Sembilan: Beberapa pandangan daripada sudut budaya. Dewan Bahasa, January, 34-43.

1994. Dialek Negeri Sembilan: Satu lambang ciri budaya Negeri Sembilan. In Negeri Sembilan, gemuk dipupuk, segar bersiram: Adat merentas zaman, eds. A. Samad Idris, Norhalim Ibrahim Muhammad Tainu and N.S. Dharmala, 365-381. Negeri Sembilan: Jawatankuasa Penyelidikan Budaya Negeri Sembilan.

Yule, G. 1996. The study of language. Cambridge: Cambridge University Press. 